\title{
The legacy of Black Consciousness: Its continued relevance for democratic South Africa and its significance for theological education
}

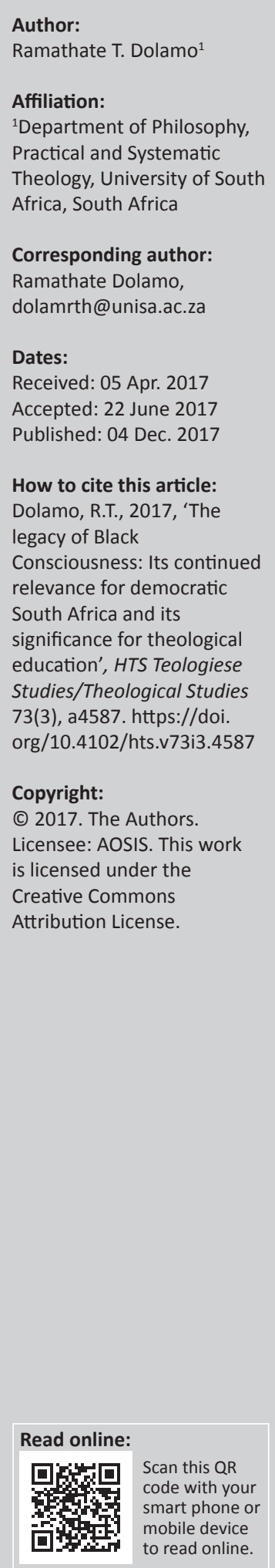

\begin{abstract}
This article argues that Black Consciousness as a philosophy transcends all political organisations and ideologies, because its architects were interested in rallying the whole country to fight apartheid regardless of political affiliation. The same consciousness that was raised in the 1960s could still influence political business today in democratic South Africa. To this end, a selection of values and principles of Black Consciousness has been examined that could be used in various sectors to ensure that our democracy is strengthened and protected. Some of those values and principles include: (1) a sense of solidarity in the face of adversity; before 1994, it was apartheid and today it is poverty; (2) the importance of the value of selfreliance in the face of unemployment and joblessness; (3) the value of self-understanding in Africa and globally as a country and (4) the critical role that education plays towards the total liberation of the whole person.
\end{abstract}

\section{Introduction}

Black Consciousness (BC) was largely a continuation of the struggle for national liberation in South Africa that had been waged by liberation movements such as the African National Congress (ANC), Pan Africanist Congress (PAC) and South African Communist Party (SACP). The difference was the approach adopted, and the methods and tactics used. Otherwise, the vision was the same, namely that the oppressed black majority were to be liberated from white supremacy. It was a philosophy that was infused in the young people in secondary schools and institutions of higher learning in the 1960s. Like the liberation movements that preceded it, BC was responding to slavery, colonialism, apartheid and collaborators with the apartheid regime such as the 'homeland' leaders and white liberals. In the 400 years or so before this, black South Africans had experienced great losses: life and limb, land, dignity and pride, self-respect, botho/ubuntu, culture, religion, political freedom and self-determination, self-reliance, and so on. In this era of democracy neo-colonialism, capitalism, the free market and its attendant neo-liberal policies are continuing to wreak havoc and perpetuate, and even deepen the gap between the rich and the poor. The black people who are in government and parliament have political power but lack economic power. Hence, some of the values and principles of BC should be revisited to determine to what extent they could be utilised to address existential challenges and problems that South Africa faces today. BC philosophy should be taught at schools and institutions of higher learning, which would make it pivotal in achieving a decolonised and empowering education.

\section{Origins of Black Consciousness}

The first paragraph of the preface to his book Politics of Black Nationalism: From Harlem to Soweto, Abraham (2003) states emphatically:

Black history did not begin, as pseudo-historians would have us believe, with the colonial encounter. The colonial period was preceded by a long and glorious black past, extending from ancient times to the 16th century. During this period, African states had evolved refined and sophisticated political and economic organisations and rich and varied cultural artifacts. The concept of 'slavery' as defined and propagated during the colonial epoch was virtually nonexistent.

Although BC as a formalised philosophy was an initiative of students and youths in the 1960s, its roots go back many years before that, a point we will elaborate on later. Stephen Bantu Biko, who was born on 18 December 1946 at Ginsberg near King William's Town in the Eastern Cape, was the initiator and cofounder of BC. He was killed for his political convictions while in police detention on 12 September 1977 (Stubbs 1978:2; Wilson 1991:15). 


\section{Defining BC, Biko (1978j) explains:}

(it) is an attitude of mind and a way of life, the most positive call to emanate from the black world for a long time. Its essence is the realization by the black man of the need to rally with his brothers around the cause of their oppression - the blackness of their skin and to operate as a group to rid themselves of the shackles that bind them to perpetual servitude. It is based on a self-examination which has ultimately led them to believe that by seeking to run away from themselves and emulate the white man, they are insulting the intelligence of whoever created them black. (p. 92)

Halisi (1991) makes the point from a psychological perspective:

The central contention of Black Consciousness philosophy was that resignation to racial domination was rooted in self-hatred and this had major political implications: the black person's low sense of self-esteem fostered political disunity, allowed ethnic leaders and other moderates to usurp the role of spokespersons for the black masses, and encourage a dependence on white leadership. Conversely, a heightened sense of racial awareness would encourage greater solidarity and mobilize mass commitment to the process of liberation. (p. 100)

Moodley (1991:152) concurs that BC helped the black masses to shed an internalised colonial mentality and it laid the ground for the self-confident challenge to the apartheid state. 'This self-empowering, vibrant, reconstructionist worldview emphasized the potential role of black initiative in responsibility in articulating the power of the powerless' (Moodley 1991:143). Moodley (1991) adds that this resolution was taken against the background of such claims as the following:
... blacks were portrayed as innately inferior, accustomed to de-humanized living, sexually promiscuous, intellectually limited, and prone to violence. Blackness symbolized evil, demise, chaos, corruption and uncleanliness, in contrast to whiteness which equaled order, wealth, purity, goodness, cleanliness and epitome of beauty. (p. 143)

The year 1652 is regarded as the beginning of the history of the black struggle against slavery, colonialism and apartheid. This was the year in which white people landed at the southernmost tip of Africa and began to settle there (Marsh 2013:207-208). The year is engrained in the minds and hearts of black people and there are deep scars to prove it. 'Colonialism and conquest brought about immense changes in the African societies of Southern Africa, impacting radically on their economies, cultures, thoughts and ways of life' (Odendaal 2012:9); elsewhere he mentioned that indigenous people had been subjugated, enslaved, deprived of their land and freedom, even in places exterminated, all in the name of Western civilization and progress' (2012:3). Mzimela (1983) concurs: 'Everywhere where people have been colonised, they have been economically exploited, politically oppressed and racially discriminated against' (p. 192). The Land Acts of 1913 and 1936 ensured that black people were stripped of $87 \%$ of their land (Changuion \& Steenkamp 2012:130-139, 163-175) and when the National Party came into power in 1948, racism in the form of apartheid was institutionalised (Changuion \& Steenkamp 2012:86-200). South Africa's ethnic groups were moulded into 'homelands' that would be given some autonomy and indeed some of them, such as Transkei, Venda, Ciskei and Bophuthatswana, were given their 'independence' by 'white' South Africa (Changuion \& Steenkamp 2012:214231, 232-250), while Indians and so-called Coloureds were to some extent accommodated in the central government through what was known as the Tricameral Parliament (Changuion \& Steenkamp 2012:252-253).

While the National Party was in power, it employed various strategies to fight against groups and individuals who were opposed to racism and white supremacy. The ANC and the PAC were banned after the Sharpeville massacre in 1960 and they went underground and formed resistance armies, namely, Umkhonto we Sizwe and POQO, respectively. The years 1960-1990 were particularly brutal and cruel for liberation movements and some individuals. Thousands went into exile after the 1976 student uprisings, and others were imprisoned both inland and on Robben Island. A great fear engulfed the whole country and people were left paralysed (cf. Brotz 1977; Davenport 1987; Lodge 1983; Motsoko 1984) and yet as Suttner (2008) correctly maintains, even at this time of pathological fear, the ANC was busy underground with its political education and the armed struggle, both inside and outside the country. That was the moment when BC came fully into the picture and as a movement it was initially allowed to operate, because the government thought that it was a movement aligned with the apartheid ideology of separate development.

\section{Black Consciousness and the liberation struggle}

A number of the then young people such as Nyameko Pityana, Mamphela Ramphele, Sabelo Ntwasa and Bennie Khoapa, led by Steve Biko, reflected on the situation in the country as it was during the 1960s and the 1970s. They read widely about African politics as well as global trends and in particular engaged with the politics of African Americans. For example, Biko is said to have read in one night the 460 pages of Autobiography of Malcom X (Sono 1993:95). Black Power ideology, Kwame Ture, Charles V. Hamilton, Franz Fanon, Martin Luther King Jnr, Paulo Freire and Elijah Muhammad were read with so much passion that when Sono evaluates BC, he comes to the conclusion that it is a $100 \%$ import from America (1993:37). They also read the works and followed the praxis of sub-Saharan African leaders whose countries were being liberated from the colonial yoke, starting with Ghana, which was the first to be decolonised when Britain granted it independence in 1957. As a result, leaders such as Kwame Nkrumah, Julius Nyerere and Leopold Senghor served as role models for those young people in South Africa (Sono 1993:37). Pityana (2008:7) adds to this list of influences on BC the Ethiopian Movement, the ANC and the PAC. Khoapa (2008) says that after studying and reflecting on all these happenings, it was concluded that:

For the oppressed the meaning of the struggle against dehumanization is located in the great humanistic and historical 
task of liberating both themselves and their oppressors. The object of the struggle is to create an order that dehumanizes no one. (p. 75)

Or put differently by Sibisi (1991):

True liberation of both the oppressed and the oppressors in South Africa will entail a recognition by both parties of the full humanity of each individual, regardless of race, class or gender. (p. 136)

The 'pathological fear' (Pityana 2008:5) that gripped the black citizenry had to be dealt with on the psychological level even before an attempt could be made at physically removing the shackles of oppression, for 'the most potent weapon of the oppressor is the mind of the oppressed'. This fear had undermined the dignity of black people and negated their humanity (Pityana 2008:6). Biko (1978h:77-79) likened apartheid to Nazism, a thesis that is treated fully by Mzimela (1983) in his doctoral study. The situation was untenable in as far as these commentators were concerned. Biko and his fellow students decided that enough was enough and that they had to make a move against the white minority regime. They decided to cancel their membership of multiracial organisations such as the National Union of South African Students (NUSAS) and the University Christian Movement (UCM) to form an exclusive black student organisation called the South African Students' Organization (SASO) in July 1969, and Biko became the organisation's first president (Biko 1978g:67; Seleoane 2008:33-34; Sono 1993:31). SASO would offer black people a platform to discuss issues peculiar to themselves, because they felt that NUSAS and UCM were preoccupied mainly with issues affecting white people.

The racial orientation and composition of SASO was a blessing in disguise, because the apartheid regime was fooled into believing that it was formed in line with the policy of separate development (Biko 1978a:5-11). But as students graduated, a concern was raised as to what would happen to them in their places of work and influence. What BC had imparted needed to be perpetuated beyond the confines of a classroom. To this end, the Black People's Convention (BPC) was launched in December 1971 (Sono 1993:81). Later, the Azanian People's Organization (AZAPO) was launched as a political party and this was followed by the establishment of the National Union of Mineworkers (NUM). With the formation of the United Democratic Front (UDF) in 1983, the struggle was taken to a higher level. All these gains were achieved in spite of the apartheid regime's crackdown on liberation organisations, their leaders, proliberation media and the death in detention of leaders such as Biko (Buthelezi 1991:129). Buthelezi (1991) puts it succinctly when he says:

The BCM can be said to have prepared the way for the bolder moves of the 1970s and 1980s, which culminated in the events of the 1990s. The impact of BCM goes beyond particular organizations. (p. 129)

\section{Ideological underpinnings}

Biko qualified from the outset what BC means by 'blackness'. There are people who think about $\mathrm{BC}$ as supportive of the policy of apartheid and those who think about BC as racially exclusive, but nothing could be further from the truth. Biko (1978e) writes:

We have in our [SASO] policy manifesto defined blacks as those who by law or tradition, politically, economically and socially are discriminated against as a group in South African society and identify themselves as a unit in the struggle towards the realization of their aspirations. (p. 48)

And he emphasises that 'What Black Consciousness seeks to do is to produce at the output end of the process real black people who do not regard themselves as appendages to white society' (1978e:51).

It is in the same vein that Biko called upon all black people that is, Africans, Indians and so-called Coloureds - to unite in solidarity against the government that pitted them against each other (Biko 1978c:33-39; 1978e:52). But he emphasises that 'blackness' is not a matter of pigmentation but a mental attitude (cf. also Moodley 1991:145). It is therefore not all people with black skins that qualify for blackness, for the purpose of this contextual definition (cf. Pityana 2008:10). People who are immediately excluded from this blackness were 'homeland' leaders who agreed to work within the apartheid system to separate black people according to their ethnic groupings (Biko 1978i:80-86). This would explain why Themba Sono was summarily removed as president of SASO when he argued that the organisation should be sympathetic to the homeland leaders and cooperate with them (Sono 1993:97). On the psychological and spiritual level, Biko (1978e) says:

Black Consciousness takes cognizance of the deliberateness of God's plan in creating black people black. It seeks to infuse the black community with a new formed pride in themselves their efforts, their religion and their outlook to life. (p. 49)

According to Biko (1978j), there is no white person who can qualify as black, even white liberals such as Donald Woods and Aelred Stubbs, mainly for the following reasons. Firstly, no white person could experience the oppression that black people were enduring, no matter how sympathetic or empathetic they were. Statements such as those made to the British audience by the celebrated white liberal, Alan Paton, when he said that apartheid should be given a chance because it could work, flew in the face of BC principles. For Paton, SASO was a product of a segregationist and racist mentality. It was myopic and ungrateful for what white people were doing for them. Unfortunately even today, 22 years into democracy, this white supremacist mentality is still prevalent among white liberals. Helen Zille, a respected politician of a white liberal party, tweeted that colonialism had done very much for black people, which is a stark example of how much work still needs to be done to eradicate racism. Secondly, Biko regarded white people as inherently paternalistic and condescending to black people, because black people were regarded as inferior and would forever need white tutelage. Thirdly, all white people were beneficiaries of apartheid and therefore their involvement in the struggle would be halfhearted and they would only seek superficial change. 
And fourthly, white people doubted the capabilities of black people and claimed that there is no way that black people could be trusted with the responsibility of running a complex and complicated country like South Africa (Biko 1978:88-91; Khoapa 2008:82-87). However, Biko (1978b) did not rule out completely the role that white people could play and he says that 'all true liberals should realise that the place for their fight for justice is within their white society' (p. 25). This message was taken to heart, because many liberals joined anti-apartheid organisations both nationally and internationally. NUSAS, UCM, the Progressive Party, Beyers Naudé, Zac de Beer, the Christian Institute responded cautiously to BC. They:

were wise enough to adopt a charitable and paternalistic attitude to the movement, and simultaneously to keep firing harsh salvos at the apartheid government, accusing it of having created this Black Consciousness phenomenon. (Sono 1993:67)

\section{Black Consciousness for life-long empowering education}

From the BC perspective, much was done in terms of rewriting and reinterpreting African history, redefining African cultures and salvaging African religion (cf. Biko 1978e:40-47; 1978f:54-60; 1978j:87-89; Buthelezi 1991:111-129; Khoapa 2008:73-87; Pityana 2008:1-14; Seleoane 2008:15-56). The contention here is that BC in this era of democracy can still contribute significantly towards the empowerment of South Africa's poor black majority, of course, in collaboration with other parties in the public and private sectors.

Without going into the complexities and indeed intricacies of what is meant by 'de-colonial education', one would like to identify elements of such a curriculum as articulated by $\mathrm{BC}$ over the last four decades. Throughout the continent, there has been and still there is a strong call for a decolonised dispensation. There is a call for a decolonised mind, education, religion, culture, language, and so on, and in South Africa since 2015 students have been marching for a 'free and decolonised education'. And, of course, this is not new for BC. In as much as BC advocates immersed themselves in the politics of the continent and beyond, younger advocates should lead the struggle for a decolonised and free education. BC as a philosophy should occupy the hearts and minds of the South African population, especially youths who are in position of leadership, power and influence. It is said that Biko was not in favour of forming a political party, but yielded for a democrat that he was (Sono 1993:81). We, therefore, do not require $A Z A P O$ to enter the fray as a custodian of the philosophy. We do not even need the Socialist Party of Azania (SOPA), which claims to be a more authentic and legitimate portal for the ideals of $\mathrm{BC}$ in general and Biko in particular. This is a philosophy that should not be monopolised by a single organisation, because its principles belong to all formations that are bent on liberating South Africa's people. This philosophy is an aspect of a movement that should be allowed to flow freely among the South African population and nourish its democratic society.
Many leaders in politics, business, religion, and so on, acknowledge their BC heritage in shaping them into what they have become (Moore 1996:14-24; Sono 1993:109-115).

\section{New national identity}

Prior to 1994, South Africa was a country with two nationalities: one black and the other white. The policy of apartheid meant that we became a pariah state among the nations of the world. But since 1994, with the dawn of democracy, we have become a respected country in the world. We are one nation under one flag and singing one national anthem - an anthem that is, of course, still problematic for some South Africans, but that exemplifies the extent to which President Mandela was prepared to go to reconcile a divided nation. A new constitution has been adopted and a new identity has been forged, hence the talk about South Africa as a 'rainbow nation'. But the process of nation building is work in process and the majority of South Africans would like to see the democratic project succeed. Sono (1993) believes that Biko would not have shunned the negotiations that brought about the demise of apartheid in the early 1990s, for Biko (1978d) said:

At some point South Africa itself will begin to want to bargain in a realistic fashion other than through Bantustans ... We want to continue mounting criticism and pressure as a people on South Africa, so that when a period of negotiations, which is inevitable in terms of our looking at history, comes, we are there to be talked to. (p. 106)

And he firmly believed that Biko would have been the strongest glue to bind together the fractious factions going under the appellation of liberation movements (1993:101). Whether Biko would have agreed to the so-called 'sunset clauses' is a matter of conjecture, a debate that should be left to his inner circle. South Africa under President Mbeki played a pivotal role on the continent with his African Renaissance project (Makgoba 1999) and BC philosophy has all the hallmarks of this pan-Africanism. According to Maloka (2002):

Pan Africanism rested on four pillars: (a) a sense of common historical experience, (b) a sense of common descent and destiny, (c) opposition to racial discrimination and colonialism, and (d) a determination to create a new Africa. (p. 4)

Who are we as South Africans on the continent? The legacy of our former African leaders, which BC leaders embraced, and on which President Mbeki latched to when he revived the African Renaissance project, must be taught to our African youth. Africa should find solutions for its problems and not look to other countries for assistance. The African Union (AU) became increasingly stronger over the years and today there are examples that prove that it can do things for itself, especially in the areas of conflict resolution and governance. Xenophobia must be tackled head on as it divides Africans on the continent at a time when Africans need each other to make Africa the prosperous and peaceful continent that it has the potential to be. We should relax colonial boundaries. We should stop referring to each other as Francophone, 
Lusophone and Anglophone countries when the AU addresses continental politics and business. South Africa is fostering a new identity and so should the AU; in fact, I believe much has been done since 2002 when the OAU was transformed into the AU. There is even an AU anthem to show for it.

\section{Black Consciousness as the salt of the earth}

As stated above, the philosophy of BC as initially conceptualised was not supposed to have been encapsulated in an institution or single organisation. It was meant to be a people's philosophy for liberation. To this end, young people were targeted to raise the awareness required to fight against apartheid and all that it stood for. There was one common enemy which all the oppressed people, regardless of ideology or political party affiliation, had to oppose and combat. As stated above, white liberals were welcomed to join the struggle, although their mission was confined to converting their fellow white compatriots to the cause of justice. Let me hasten to add that an armed struggle was never an option for BC leaders, although informally, leaders debated the merits and demerits of an armed struggle (Mokoape \& Mtinso 1991:138-139). Sono (1993:106) is emphatic that for Biko, violence against the apartheid regime was not an option. He would negotiate and bargain, even if it took decades. This should explain why the 1976 march against Bantu Education, Afrikaans as medium of instruction and the whole apartheid edifice by the Soweto school children was peaceful. The violence that ensued was unleashed by the police and other 'law and order' agencies. A number of workshops would be conducted by university students and theology seminarians during school holidays across the country. University students who were expelled because of their political activism were employed as teachers at high schools and they used the opportunity to teach BC. After 1994, we have 'monopoly capital' as the common enemy. Capitalism chases after profit on the backs of the poor and the working class. As capitalists extend their profit margins, poor people are increasingly being marginalised and hindered from enjoying the fruits of their labour. The courage and bravery that characterised the militant youth of the mid-1960s and later should be infused into the youth of today because the fight against poverty is just as important as the struggle against apartheid. The success of the industrial strikes of 1970s, especially in Natal, is a case in point. Workers refused to sell their labour for slave wages. The Marikana mine strikes which unfortunately resulted in the deaths of scores of miners demonstrated to the world the extent to which they were prepared to go to fight for their rights and dignity as human beings; and much more could be achieved if the workers' unions could transcend their own political and ideological affiliations. BC's transcendence over political parties should be able to unite all South Africans against 'white monopoly capital'. It should be sprinkled like salt on the South African population so that a concerted effort should be directed at the socio-economic emancipation of the poor, most of whom are black people. It must be acknowledged that Sono (1993) disagrees that BC, in its present composition, would have a role to play in the democratic South Africa:

Were the $\mathrm{BCM}$ revolutionaries to guarantee the delivery of the political needs of today, they would most likely be competitive. But to do so the BCM will have to change its modalities and perspectives dramatically. To that extent then it would have ceased being a BC formation. (p. 131)

\section{Self-reliance}

'There is a lot of community work that needs to be done in promoting a spirit of self-reliance and black consciousness among all black people in South Africa' (Biko 1978c:38). Leaders of BC knew very well that national liberation would not automatically translate into prosperity for all. As indicated above, people were encouraged and assisted to do things for themselves instead of waiting upon benefactors for charity and donations. Bursaries and scholarships were organised for deserving poor pupils and students, especially for those whose parents were detained for political reasons. The poor, especially those who had been detained and later released, were given seed funding to start all sorts of smallscale businesses in agriculture and industries, for example, and some jobs were created along the way. Charity perpetuates poverty and strips people of their dignity (Ramphele 1991:154-178). The government cannot fight poverty by dishing out welfare grants at will. Those who are elderly, sickly or disabled should, by all means, benefit from welfare grant schemes. But some grants are more questionable, such as those given to pregnant school girls and free housing. How about giving the poor building materials and let them build the houses themselves? BC's approach to fighting poverty should come in handy here. The one sure way to get the poor out of the cycle of poverty is to create jobs. The culture of entitlement and corruption is stunting the growth of South Africa's economy. When people get things free, they lose the sense of ownership of the things they have and, as a result, they do not become stewards of the assets of the country. Some black people do not appreciate that since 1994 they have owned all societal and state assets. No wonder when communities demand a tarred road, they burn a clinic, and when they demand water, they burn a school or clinic. When they demand 'free and decolonised education', they burn a library or a laboratory. We can only acquire more assets if we preserve existing ones. We need a development trajectory that will encapsulate Ramphele's (1991) idea that:

(development) as a process of empowerment ... enables participants to assume greater control over their lives as individuals and members of societies. It is a process of capacity building and empowerment of people working for a preferred and shared future. (p. 157)

\section{Research, knowledge production and education}

Everybody agrees that education is vital for the liberation of the mind and body. BC as a philosophy that was invented by young people was steeped in an understanding of the value of education. Conscientisation workshops held during school holidays were aimed at empowering young people to know 
their history and their purpose in life as well as shaping their own destiny. 'Conscientization was ... fundamental to Black Consciousness programmes. Through cultural activities such as drama, music, youth activities, Black Consciousness was taught' (Sono 1993:72). The leaders themselves were educated people and were intellectuals in their own right. Decolonised curricula should be crafted that could be offered from primary school to tertiary level. There should be a policy on free compulsory education so that no single child or student might be excluded on financial grounds. In order for such curricula to be crafted, Africans should write the study material themselves and discard those written about them by others. BC had already realised this truth in the 1970s, when journals such as Black Review and Black Viewpoint were launched (Ramphele 1991:162). After the decolonisation process in Africa began, people delved into their histories to prove that African religion, philosophy and culture, in general, were far superior to any civilisation in the world. Features that we today marvel in terms of science, mathematics, education, governance, technology, and so on, were shown to have been started by Africans (cf. Makgoba 1999).

\section{Significance for theological education}

Black Theology (BT) was conceptualised almost simultaneously with $\mathrm{BC}$ for some of the $\mathrm{BC}$ leaders were the same as BT leaders. People such as Biko, Pityana, Motlhabi, Mosala, Maimela and Khoapa fall into this category. Biko, for example, did not renounce his membership of UCM and he, in fact, drove the BT project with the assistance of some theology students (Sono 1993:29). BC and BT shared the same ideological basis to such an extent that conclusions such as the following were drawn: 'Black Theology ... is an extension of Black Consciousness' (Pityana 1972:41), 'Black Theology is the theological aspect of Black Consciousness' (Motlhabi 1972:55) and '(Some) ordinands and lay people were deeply influenced by Black Consciousness and its soulmate, Black Theology' (Duncan 2008:116). Within the SASO leadership, responsibilities were shared and Biko and Pityana were given the responsibility for political and theological matters (Wilson 1991:29). How was BT understood? For Biko (1978f):

Black Theology ... is a situational interpretation of Christianity. It seeks to relate the present-day black man to God within the given context of the black man's suffering and his attempts to get out of it ... (it is) committed to eradicating all causes of suffering as represented in the death of children from starvation, outbreaks of epidemics in poor areas, or the existence of thuggery and vandalism in townships. (p. 59)

\section{Biko (1978j) continues:}

(BT) seeks to relate God and Christ once more to the black man and his daily problems. It wants to describe Christ as a fighting God, not as a passive God who allows a lie to rest unchallenged. It grapples with existential problems and does not claim to be a theology of absolutes. It seeks to bring back God to the black man and to the truth and reality of his situation. (p. 94)
Motlhabi (1972), one of the foremost exponents of BT, has the following to say regarding the nature of BT:

Black Theology is not a new theology nor is it a proclamation of a new gospel. It is merely a re-evaluation of the gospel message, a making relevant of this message according to the situation of the people ... Its advocates believe that Christ not only has something to do and offer my 'soul' but to 'me' in my entire situation and condition here and now ... Its true meaning is coextensive with suffering, of the majority in this country is 'not white', 'Black' is rightly used, affirming that whiteness is not the only value in relation to which everything else should be considered. (pp. 56-57)

Black Theology is therefore situational and not time-bound as some might think. It will continue to address new questions and confront new challenges as they arise.

As we know, the colonialists and traders were in cahoots with the missionaries. As colonialists denigrated African culture and civilisation as savage and barbaric, missionaries demonised African religion as heathen and pagan. Therefore, the theology that was taught in theological seminaries was a theology that was 'white' and was emptied of all Africanity. Biko, Ramphele, Sabelo and others visited theological seminaries throughout the country to influence the students as well as staff to revise their curriculum. It was supposed to be a curriculum that would address the existential needs and aspirations of black people (Duncan 2008:115-140; Motlhabi 2008:3-7; Stubbs 1978:158). Under the leadership of Pityana, for example, BT at Fort Hare University flourished and the curriculum there, placed a heavy emphasis on practical theology, community outreach and engagement (Duncan 2008:133). As a result, many seminaries and universities, especially historically black universities as well as the University of South Africa, included in their course material Latin American Liberation Theology, US Black Theology and South African Theology. That enthusiasm has seemed to be receding since 1994 unfortunately. Some theologians, even black ones, have substituted the term BT with terms such as 'Theology of Reconstruction' and 'Public Theology'. Indeed, we are faced today with issues of nation building and reconciliation. How are we to teach the relationship of such concepts to restorative justice, for example? Seminaries and universities should Africanise theological education in such a way that those who graduate from such entities are fully equipped to deal with the socio-economic realities in South Africa today. Capitalism and neo-liberal concepts should be taught at our theological institutions. Globalisation and its drivers, the multinationals, World Bank and WTO should be integrated into theological education so that the graduateness of theologians should be made manifest in their pastoral ministry and research. For example, if ecology was taught from an African perspective, where conservation and preservation are prominent, and not from the Western perspective, where profit is of paramount importance, the dangers and consequences of climate change would not even arise. Tenets of African religion and culture should be resuscitated when teaching theology as values and principles can be learned to save our finite planet. In as much as it is 
good to learn from classical white scholars, we must include a high dosage of classical African scholars, who are accessible in abundance. The primacy and centrality of the Bible is obviously crucial as that is what makes us Christians, while the research done by Oden (2007) is helpful in understanding African Christianity and Western Christianity.

\section{Conclusion}

I am convinced that the abiding relevance of $\mathrm{BC}$ cannot be doubted. What perhaps needs to be looked into are the strategies for fighting present-day challenges, especially on the socio-economic front. For instance, the scepticism that was directed at white liberals since the 1960s should now be directed at 'monopoly capital', irrespective of whether it refers to black or white businesses. And, of course, globally, we should reassess our relationship with the multinational corporations as well as institutions such as the World Bank, International Monetary Fund and World Trade Organization. Racism was not vanquished with the advent of democracy and we must add classism to the list of social ills as well as xenophobia. Obviously, these are areas that need more research. At the height of apartheid people fought side by side regardless of their party political affiliation, class, religion or gender. The formation of the UDF is a case in point. We pushed and pushed until the walls of apartheid fell like the walls of Jericho in the Bible. As stated above, Biko wished for BC to become a philosophy for all South Africans, because it transcended party politics and ideologies. Perhaps, Biko would find it appropriate that we do not have a single BC political party in parliament, because this means that individuals, regardless of party affiliation, can apply their BC philosophy to influence legislation that will lead to 'radical transformation' of the economy of the country. We need to become one nation, black and white under one flag to work for the good of the nation without trying to score cheap political points at the expense of other political parties. Of course, as a democracy, we need to have honest and robust debates as we form and shape the kind of a society in which all citizens, as well as foreign nationals, will be happy and safe to live. Theology, in general, and BT, in particular, should work hand in hand with civil society and movements that are in the struggle to eradicate the fundamental problem of poverty in society.

\section{Acknowledgements Competing interests}

The author declares that he or she has no financial or personal relationships which may have inappropriately influenced him or her in writing this article.

\section{References}

Abraham, K., 2003, Politics of black nationalism: From Harlem to Soweto, Africa World Press, Inc., NJ.

Biko, S., 1978a, 'Black consciousness and the quest for true humanity', in A. Stubbs (ed.), I write what I like, pp. 87-98, The Bowerdean Press, London.

Biko, S., 1978b, 'Black souls in white skins', in A. Stubbs (ed.), I write what I like, pp. 19-26, The Bowerdean Press, London.

Biko, S., 1978c, 'Fear: An important determinant in South Africa', in A. Stubbs (ed.), I write what I like, pp. 73-79, The Bowerdean Press, London.
Biko, S., 1978d, 'Fragmentation of the black resistance', in A. Stubbs (ed.), I write what I like, pp. 33-39, The Bowerdean Press, London.

Biko, S., 1978e, 'Let's talk about Bantustans', in A. Stubbs (ed.), I write what I like, pp. 80-86, The Bowerdean Press, London.

Biko, S., 1978f, 'SASO - Its role, its significance and its future', in A. Stubbs (ed.), I write what I like, pp. 3-7, The Bowerdean Press, London.

Biko, S., 1978g, 'Some African cultural concepts', in A. Stubbs (ed.), I write what I like, pp. 40-47, The Bowerdean Press, London.

Biko, S., 1978h, 'The church as seen by a young layman', in A. Stubbs (ed.), I write what I like, pp. 54-60, The Bowerdean Press, London.

Biko, S., 1978i, 'The definition of black consciousness', in A. Stubbs (ed.), I write what I like, pp. 48-53, The Bowerdean Press, London.

Biko, S., 1978j, 'White racism and black consciousness', in A. Stubbs (ed.), I write what I like, pp. 61-72, The Bowerdean Press, London.

Brotz, H., 1977, The politics of South Africa, Oxford University Press, London.

Buthelezi, S., 1991, 'The emergence of black consciousness', in B. Pityana \& M. Ramphele (eds.), Bounds of possibility: The legacy of Steve Biko and black consciousness, pp. 111-129, David Philip, Cape Town.

Changuion, L. \& Steenkamp, B., 2012, Disputed land: The historical development of the South African land issue, Protea Book House, Pretoria, pp. 1652-2011.

Davenport, T.R.H., 1987, South Africa: A modern history, Macmillan Press, London.

Duncan, G., 2008, Steve Biko's religious consciousness and thought and its influence on theological influence with special reference to the federal theological seminary of Southern Africa, UNISA, Pretoria, pp. 115-140.

Halisi, C.R.D., 1991, 'Biko and black consciousness philosophy', in N.B. Pityana \& M. Ramphele (eds.), Bounds of possibility: The legacy of Steve Biko \& black consciousness, pp. 100-110, David Philip, Cape Town.

Khoapa, B., 2008, 'African diaspora: Intellectual influences on Steve Biko', in C.V. du Toit (ed.), The legacy of Stephen Bantu Biko, pp. 73-87, Unisa, Pretoria.

Lodge, T., 1983, Black politics in South Africa Since 1945, Ravan Press, Johannesburg.

Makgoba, M.W., 1999, African renaissance, Mafube Publishers Ltd, Sandton.

Maloka, E., 2002, 'Towards the African Renaissance: The African Union and the New Partnership for Africa's Development (NEPAD), in Report on the 9th Conference of Africanists, Moscow.

Marsh, R., 2013, Understanding Africa and the events that shaped its destiny, LAPA Publishers, Pretoria.

Mokoape, K. \& Mtinso, T. (eds.), 1991, 'Towards the armed struggle', in N.B. Pityana \& M. Ramphele (eds.), Bounds of possibility: The legacy of Steve Biko, pp. 137-142, David Philip, Cape Town.

Moodley, K., 1991, 'The continued impact of black consciousness', in N.B. Pityana \& M. Ramphele (eds.), Bounds of possibility: The legacy of Steve Biko \& black consciousness, pp. 143-152, David Philip, Cape Town.

Moore, B., 1996, 'Black theology revisited', in K.C. Abraham (ed.), Voices from the third world, vol. xix, no. 2, pp. 7-45, BTESSC, Bangalore, India.

Motlhabi, M., 1972, 'Black theology', in M. Motlhabi (ed.), A personal opinion, pp. 53-59, University Christian Movement, Johannesburg.

Motlhabi, M., 2008, African theology/black theology in South Africa: Looking back, moving on, UNISA, Pretoria.

Motsoko, P., 1984, Apartheid: The story of a dispossessed people, Marriam Books, London.

Mzimela, S.E., 1983, Apartheid: South African Naziism, Vantage Press Inc., New York.

Oden, T.C., 2007, How Africa shaped the Christian mind, Intervarsity Press, Downers Grove, IL.

Odendaal, A., 2012, The founders: The origins of the ANC and the struggle for democracy in South Africa, Jacana Media, Johannesburg.

Pityana, B., 2008, 'Reflections on 30 years since the death of Steve Biko: A legacy revisited', in C.W. du Toit (ed.), The legacy of Stephen Bantu Biko, pp. 1-14, UNISA, Pretoria.

Pityana, N.B., 1972, 'What is black consciousness?', in M. Motlhabi (ed.), Essays on black theology, pp. 37-43, University Christian Movement, Johannesburg.

Ramphele, M., 1991, 'Empowerment and symbols of hope', in N.B. Pityana \& M. Ramphele (eds.), Bounds of possibility: The legacy of Steve Biko, pp. 154-178, David Philip, Cape Town.

Seleoane, M., 2008, 'The development of black consciousness as a cultural and political movement (1967-2007)', in C.W. du Toit (ed.), The legacy of Stephen Bantu Biko, pp. 15-56, UNISA, Pretoria.

Sibisi, C.D.T., 1991, 'The psychology of liberation', in N.B. Pityana \& M. Ramphele (eds.), Bounds of possibility: The legacy of Steve Biko and black consciousness, pp. 130-136, David Philip, Cape Town.

Sono, T., 1993, Reflections on the origins of black consciousness in South Africa, HSRC, Pretoria.

Stubbs, A., 1978, 'Martyr of hope', in A. Stubbs (ed.), I write what I like, pp. 154-216, The Bowerdean Press, London.

Suttner, R., 2008, ANC underground in South Africa to 1976, Jacana Media, Johannesburg.

Wilson, L., 1991, 'Bantu Stephen Biko: A life', in N.B. Pityana \& M. Ramphele (eds.), Bounds of possibility: The legacy of Steve Biko \& black consciousness, pp. 15-77, David Philip, Cape Town. 